\title{
Pemodelan Pola Aliran Fluida Panas Manifestasi Hidrotermal Songgoriti, Kota Batu Menggunakan Metode Self-Potential
}

\author{
Anggi Arwin Pratama, Ayi Syaeful Bahri, dan Dwa Desa Warnana \\ Departemen Teknik Geofisika, Fakultas Teknik Sipil dan Perencanaan, Institut Teknologi Sepuluh Nopember (ITS) \\ e-mail: syaeful_b@geofisika.its.ac.id
}

\begin{abstract}
Abstrak-Penelitian aliran fluida panas telah dilakukan di daerah manifestasi hidrotermal Songgoriti menggunakan metode pengukuran Self-Potential. Penelitian ini bertujuan untuk mendapatkan pola aliran fluida panas dan letak kedalaman anomali fluida panas di daerah Songgoriti, Kota Batu. Metode Self-Potential efektif digunakan untuk penelitian ini karena metode tersebut dapat digunakan untuk menentukan nilai potensial alami bawa permukaan, sehingga karakteristik beda potensial fluida panas bawah permukaan dapat ditentukan. Pengambilan data Self-Potential menggunakan konfigurasi leapfrog dengan jumlah titik pengukuran 100 datum. Hasil pengukuran menunjukkan karakteristik fluida panas diasumsikan sebagai anomali tinggi sekitar 60 sampai $85 \mathrm{mV}$. Hal itu dikarenakan fluida panas berasosiasi dengan batuan teralterasi sehingga bersifat termal konduktif. Proses konduksi termal di daerah penelitian diindikasikan berasosiasi dengan zona alterasi hidrotermal yang menyebabkan peningkatan nilai anomali self-potential yang terdistribusi merata pada daerah tersebut dan mempengaruhi aliran lokal. Aliran fluida teridentifikasi pada kedalaman 78 hingga 150 meter dengan pola aliran mengalir dari zona manifestasi berarah ke timur dan barat.
\end{abstract}

Kata Kunci-Fluida panas, Self-potential, Anomali, Pemodelan.

\section{PENDAHULUAN}

$S_{\text {o }}^{\mathrm{L}}$ UMBER panas bumi berasal dari hasil pemanasan fluida oleh suatu sumber panas misalnya magmatis. Maka pada umumnya sumber panas bumi berasosiasi dengan aktifitas vulkanik baik langsung maupun tidak langsung. Untuk itu biasanya daerah penelitian sumber panas bumi berlokasi disekitar daerah gunung berapi yang sudah tidak aktif. Daerah penelitian kali ini berfokus pada manifestasi panas bumi Songgoriti kota Batu. Manifestasi Songgoriti berupa mata air panas yang berasosiasi dengan sistem panas bumi gunung Kawi.

Pemetaan panas bumi sangat diperlukan untuk dapat mengeksploitasi sumber dayanya dengan mengetahui pola aliran fluida panas. Untuk memetakan pola aliran fluida panas digunakan metode geofisika salah satunya self-potential. Metode self-potential dapat memetakan pola aliran hidrotermal sistem panas bumi sehingga sebaran dapat terlihat secara regional. Secara konseptual, SP adalah teknik yang sangat sederhana dan serbaguna karena sinyal listrik yang ada di dalam media penghantar listrik (seperti bumi) dapat dideteksi dari jarak yang jauh dari lokasi mekanisme gaya. [1]

Pemetaan pola aliran fluida didapat dari peta isopotensial yang menerangkan sebaran potensial. Pengolahan selfpotential sering menghasilkan error sehingga diperlukan komparasi dan korelasi dengan data hasil pemodelan kebelakang dan kedepan (inverse and forward modelling). Pembuatan model bertujuan untuk meminimumkan anomali perhitungan dari anomali hasil pengukuran, sehingga diperlukan perbandingan kesuaian model yang dibuat dengan model sebenarnya. Dari permasalahan diatas, pada kasus ini diambil studi kasus pada manifestasi hidrotermal Songgoriti Kota Batu dengan pemetaan fluida panas yang hasilnya akan dilakukan pemodelan sehingga didapatkan model akurat untuk investigasi pola aliran fluida panas yang tersebar pada salah satu potensi panas bumi daerah Songgoriti Kota Batu.

\section{TINJAUAN PUSTAKA}

\section{A. Konsep Self-Potential}

Dikatakan Potensial diri karena potensial dihasilkan dari dalam bumi dengan berbagai sumber melalui proses fisika dan kimia. Metode ini bersifat pasif, dalam artian kita tidak memberikan sumber arus tambahan jadi pengukuran potensial dikur secara alamiah antara dua titik pada permukaan tanah. Potensial yang diukur mencakup satu milivolt $(\mathrm{mV})$ sampai satu volt dengan tanda positif dan negatif. Faktor utama yang mempengaruhi potensial diri secara umum ialah air tanah. Potensial diproduksi oleh aliran air tanah, dengan berperan sebagai elektrolit dan pelarut dari mineral yang berbeda. Ada tiga cara dalam mengkonduksikan listrik melalui batuan yaitu dengan dielektrik, elektrolitik, dan konduksi elektronik. Konduktivitas listrik ( $\sigma$, inversi dari resistivitas) dari batuan berpori bergantung pada porositasnya ( bentuk pori-porinya) dan pada pergerakan air ( atau cairan lainnya) melewati celah pori-pori (bergantung pada sifat mobilitas ionik dan konsentrasi larutan, fiskositas ( $\eta$ ), temperatur serta tekanan).

\section{B. Geologi Regional Songgoriti}

Secara umum geologi daerah Songgoriti terletak pada endapan vulkanik kuarter. Awal kegiatan didahului oleh aktivitas Gunung Anjasmara Tua (Qpat) yang diperkirakan berumur Plistosen Awal - Tengah. hasil aktivitas ini menghasilkan breksi gunung - api, breksi tuf, tuf dan lava. 
Gunung Kawi - Butak (Qpvp) dan Gunung Arjuna Welirang (Qvaw). Hasil letusan Gunung Kawi - Butak berada di selatan songgoriti sedangkan hasil aktivitas Gunung Arjuna - Welirang berada di sisi timur dan utara songgoriti. Hasil letusan Gunung api Gunung Kawi - Butak (Qpvp) berupa lava andesit, tuf, dan breksi vulkanik. Sedangkan Gunung Arjuna- welirang (Qvaw) berupa breksi gunung api, lava, breksi dan tuf.

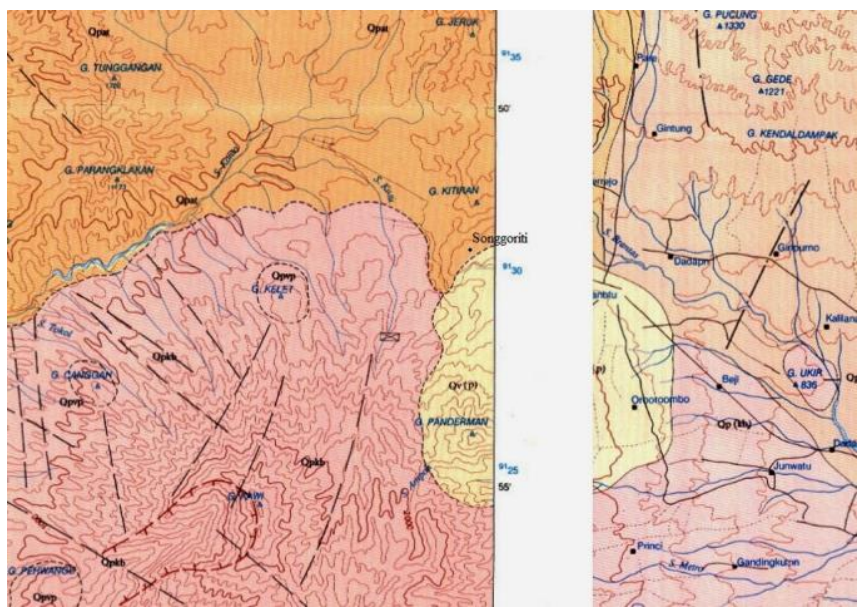

Gambar 1. Peta geologi regional Songgoriti lembar Kediri dan Malang.

Pada umur Holosen kemudian diperkirakan terbentuk Gunung Panderman yang berada di selatan Songgoriti. Hasil endapan aktifias Gunung Panderman (Qvp) ini berupa breksi gunungapi, tuf breksi,lava dan tuf. Ketiga gunung api inilah yang akan mempengaruhi potensi panas bumi di songgoriti batu.struktur geologi yang mempengaruhi daerah ini berupa sesar - sesar mendatar di bagian selatan dan sebagian berupa sesar turun akibat dari letusan gunung api. sesar - sesar inilah yang membawa manisfestasi dari dalam keluar permukaan. Menurut dinas ESDM Jawa Timur potensi panas bumi Songgoriti diperkirakan sebesar $25 \mathrm{MW}$. potensi ini merupakan hasil penelitian yang dilakukan oleh dinas ESDM jawa timur. Berdasarkan penelitian dinas ESDM diperkirakan potensi ini berada seluas $5 \mathrm{~km} 2$. Dengan suhu permukaan berkisar antara 32 - 46 derajat celcius. Dari suhu permukaan itu diperkirakan temperatur reservoar / geotermal sebesar 140 derajat celcius. Secara umum potensi panas bumi songgoriti ini berasosiasi dengan kegiatan magmatisme volkanisme yang berumur kuarter dan berada di kedalaman kurang dari $1,5 \mathrm{~km}$. Sistem panas bumi ini dikenal dengan sistem hidrotermal.

\section{METODOLOGI}

Metodologi dalam penelitian ini adalah: 1. Akuisisi data self-potential di Songgoriti, Kota Batu 2. Koreksi data selfpotential berdasarkan koreksi waktu 3. Pengolahan data selfpotential dengan output peta isopotensial dan profil bawah permukaan 4. Interpretasi pola aliran fluida panas.

\section{HASIL DAN PEMBAHASAN}

\section{A. Interpretasi Pola Aliran Fluida Panas}

Pengukuran Self-Potential dilakukan pada daerah penelitian secara pemetaan Self-Potential 1D dan 2D. Untuk pengukuran
SP 2D menggunakan teknik leap-frog dengan titik akuisisi menyebar pada area penelitian. Akuisisi 2D menggunakan jarak 10 meter tiap titik dengan jumlah titik akuisisi sebanyak 100 titik. Pengukuran dilakukan dengan menggunakan pedoman base yang ditanam pada satu titik sehingga selama melakukan pengukuran dapat dilakukan koreksi nilai SP berdasarkan waktu, dikarenakan nilai SP akan berubah-ubah pada setiap waktu karena beda potensial yang dihasilkan bumi dipengaruhi potensial elektrokinetik, elektrokimia dan mineralisasi bawah permukaan. Nilai SP pada base berubah bervariasi selama proses akuisisi data sehingga dapat dilakukan koreksi baseline harian.
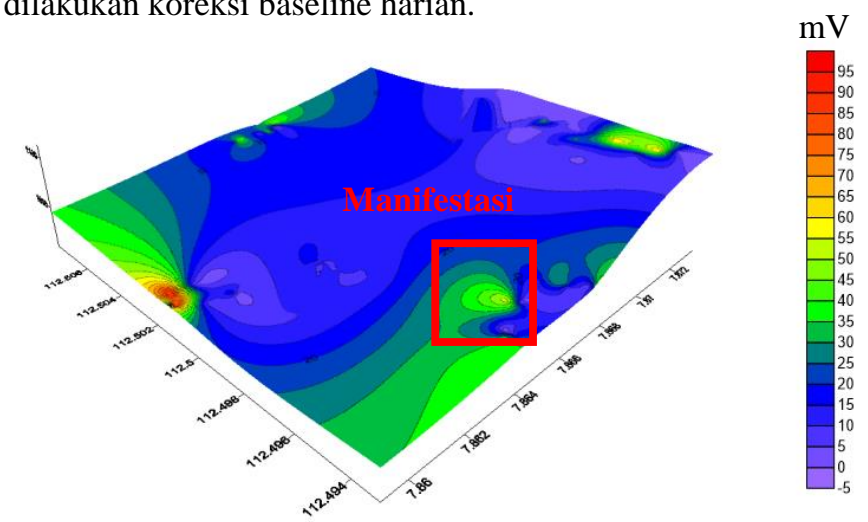

Gambar 2. Peta Isopotensial; persebaran nilai beda potensial pada daerah penelitian: Songgoriti, Kota Batu

Persebaran nilai SP yang telah dilakukan koreksi diolah menjadi peta isopotensial (Gambar 2) yang menggambarkan persebaran nilai SP pada area penelitian. Berdasarkan analisa data diperlihatkan adanya adanya anomali di daerah ini. Nilai isopotensial yang terbaca pada daerah ini berkisar pada nilai -5 $\mathrm{mV}$ sampai dengan $95 \mathrm{mV}$. Acuan nlai SP fluida panas yaitu sekitar $65-80 \mathrm{mV}$, didapatkan memalui sampe pengukuran SP diatas zona manifestasi. Pada daerah anomali yakni daerah dengan tonjolan besar nilai potensialnya -5 sampai dengan -12 $\mathrm{mV}$. Nilai potensial yang sangat kecil mengindikasikan daerah yang konduktif. Berdasarkan peta kontur isopotensial yang telah dibuat dapat diinterpretasi bahwa daerah penelitian adalah zona konduktif. Zona anomali potensial paling negatif ditemukan di kawasan selatan hingga barat daya daerah penelitian dengan nilai potensial diri mencapai $90 \mathrm{mV}$. Hal ini mengindikasikan bahwa di zona tersebut kemungkinan terdapat sumber aliran fluida panas bawah permukaan yang cukup dangkal.Hasil pengukuran data SP menunjukkan bahwa pengukuran aliran fluida panas cenderung bersifat resistif yang ditunjukkan oleh nilai SP yang relative sedang (nilai SP maksimum sekitar $95 \mathrm{mV}$ ). Pada jarak sekitar zona titik tengah nilai SP terukur sangat kecil dan bersifat resistif. Aliran air panas dari reservoir cenderung mengalir dari barat ke timur (arah atas menandakan arah utara). Hasil pengukuran data SP menunjukkan bahwa pengukuran cenderung bersifat resistif yang ditunjukkan oleh nilai SP yang relative sedang (nilai SP maksimum sekitar $95 \mathrm{mV}$ ). Aliran air panas dari manifestasi cenderung mengalir dari barat ke timur. 


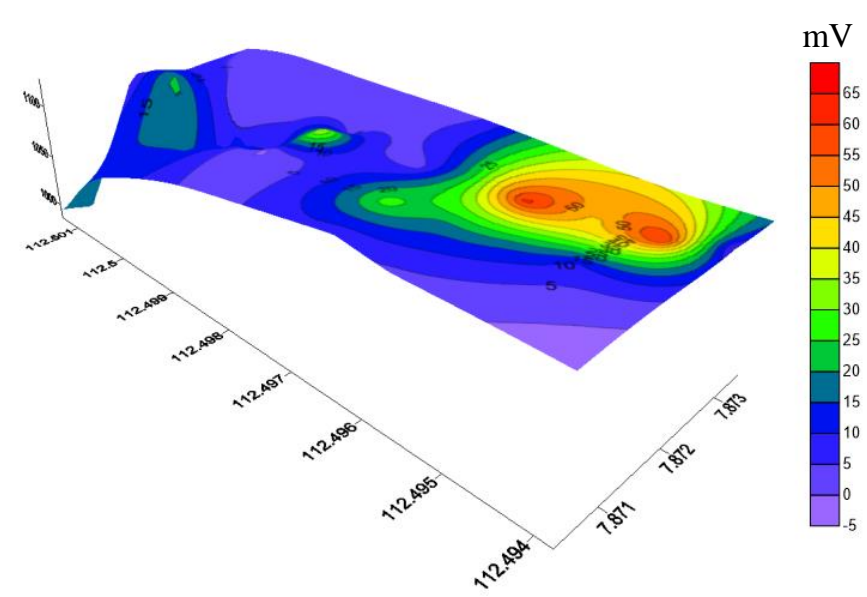

Gambar 3. Peta Isopotensial pada zona manifestasi; nilai beda potensial tinggi berpusat pada zona manifestasi

Pada zona manifestasi (Gambar 3) didapatkan rentang nilai $5-65 \mathrm{mV}$. Pada titik yang tepat diatas kandungan fluida panas nilai SP terukur sebesar $65 \mathrm{mV}$ sehingga dapat diasumsikan nilai SP pada fluida panas dapat digunakan acuan dalam identifikasi persebaran disekitar area tersebut.

Interpretasi secara kuantitatif dipakai untuk menentukan parameter dari benda sehingga didapatkan kedalaman serta sudut polarisasi. Keberadaan mata air panas (hot springs) di daerah hidrotermal di Songgoriti merupakan indikasi kemungkinan adanya suatu sistem geotermal. Perubahan fisika batuan reservoar seperti porositas dan permeabilitas dapat terjadi karena alterasi hidrotermal, sedangkan pengaruh dari alterasi hidrotermal adalah menurunnya porositas.
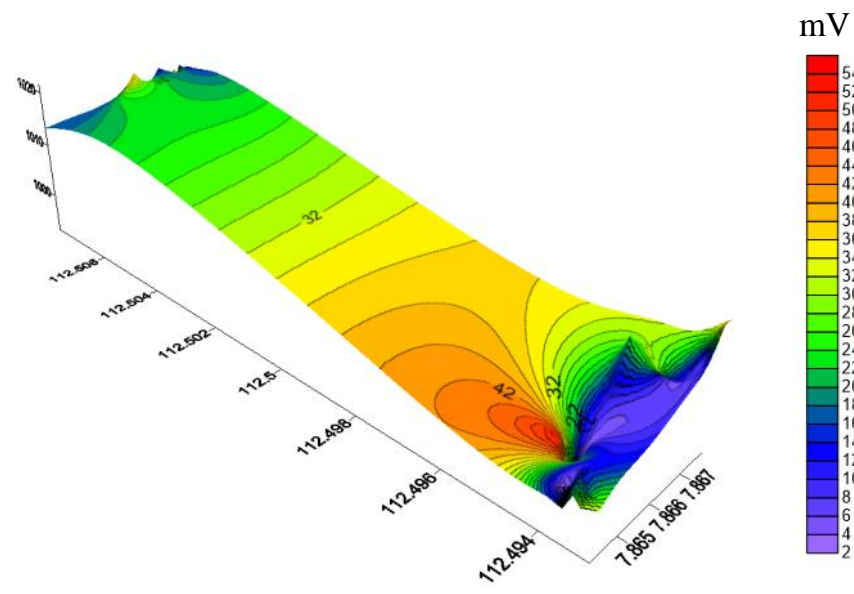

Gambar 4. Peta Isopotensial Anomali Area Utara; persebaran anomali yang berprospek adanya aliran fluida panas

\section{B. Pemodelan Inversi Satu Dimensi}

Pemodelan satu dimensi pada anomali SP dilakukan untuk mengetahui parameter-parameter berupa kedalaman, sudut polarisasi, dan momen dipol listrik. Pemodelan dilakukan dengan mengiput nilai potensial dari beberapa titik anomali pada peta isopotensial.

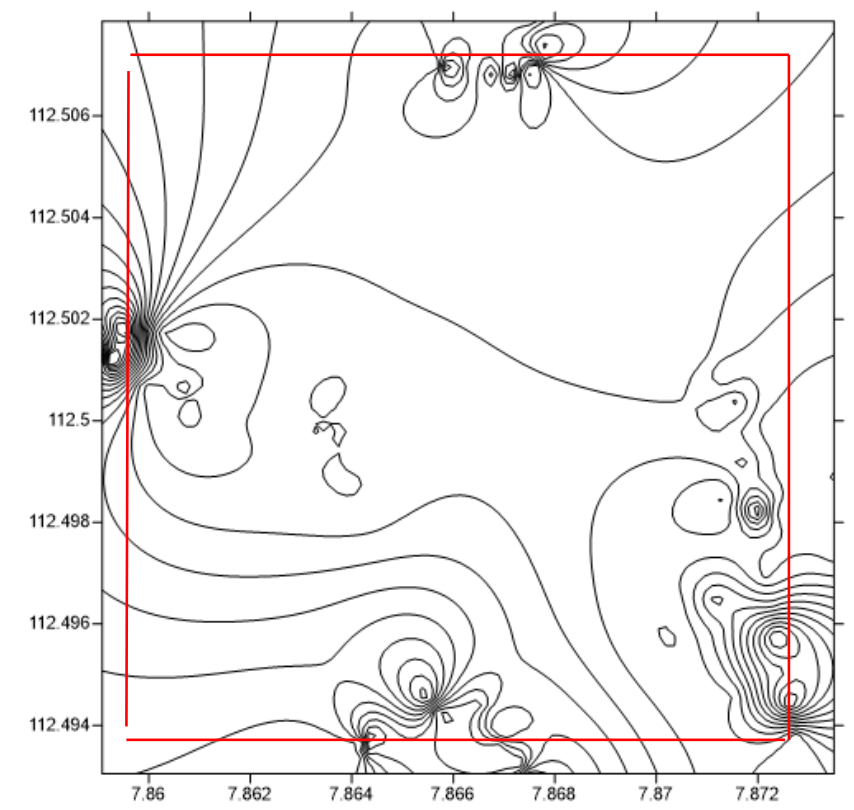

Gambar 5. Line anomali inversi satu dimensi; beberapa line anomali diambil untuk inversi 1D dengan output parameter fisis

Program MATLAB diaplikasikan pada data penelitian untuk mendapatkan parameter-parameternya. Profil anomali ini didijitasi sebanyak 20 titik dengan interval $40 \mathrm{~m}$. Selanjutnya, proses dilakukan inversi dengan melakukan pendekatan untuk ketiga bentuk sumber anomali (sphere, horizontal cylinder, dan vertical cylinder) dan perhitungan nilai RMS error. Hasil dari proses inversinya menunjukkan bahwa model sphere yang paling mendekati kondisi sekunder (sebenarnya) karena memiliki nilai RMS error terkecil.

Parameter hasil pemodelan 1D mengindikasikan letak kedalaman anomali berupa potential streaming. Aliran fluida panas dengan indikasi nilai potensial tinggi dengan asumsi zona alterasi yang bersifat konduktif mengandung fuida panas sehingga kedalaman anomali merupakan indikasi penyebaran fluida panas mengalir pada kedalaman lebih dalam pada arah utara-timur dikarenakan zona upflow berada pada anomali 3 . Aliran pada arah utara-timur terletak pada kedalaman 100-160 $\mathrm{m}$, sesuai kondisi geologi daerah penelitian menunjukkan patahan sebagai pengontrol zona upflow hanya terdapat pada area anomali 1 dan 3 .

Gambar 2 terletak pada topografi lebih tinggi daripada area

Tabel 4.

manifestasi sehingga diasumsikan terdapat zona upflow aliran fluida panas. Namun pada topografi tinggi ketinggian topografi atau perubahan elevasi akan berpengaruh juga terhadap "arus telluric". Kombinasi kedua efek terhadap anomali SP akan sulit dilakukan tetapi secara umum koreksi terhadapnya dapat dilakukan.

\begin{tabular}{lccccc}
\hline \multicolumn{5}{c}{ Parameter hasil inversi 1D } \\
\hline \hline No. & Line & $\begin{array}{c}\text { Shape } \\
\text { Factor }\end{array}$ & Kedalaman & $\begin{array}{c}\text { Sudut } \\
\text { Polarisasi }\end{array}$ & Error \\
\hline 1. & Anomali & & -76.4 & 3.4 \\
2. & Anomali 1 & 0.98 & $82.1 \mathrm{~m}$ & -85.9 & 5.8 \\
3. & Anomali 2 & 1.0 & $158.0 \mathrm{~m}$ & 72.4 & 2.6 \\
4. & Anomali 3 & 1.4 & $108.4 \mathrm{~m}$ & 42.8 & 10.3 \\
\hline \hline
\end{tabular}




\section{KESIMPULAN/RINGKASAN}

Dari penelitian yang sudah dilakukan didapatkan kesimpulan sebagai berikut:

1) Nilai beda potensial pada daerah penelitian berkisar antara 5-85 $\mathrm{mV}$ dengan nilai terbesar terdapat pada daerah manifestasi.

2) Berdasarkan hasil inversi 1D least square didapatkan kedalaman anomali 78-158 meter dan shape factor anomali berbentuk vertical cylinder dan horizontal cylinder berdasarkan inversi 1D.
3) Anomali pada daerah penelitian dominan berupa zona konduktif batuan alterasi yang berasosiasi dengan fluida panas.

4) Pola aliran fluida panas mengalir dari zona upflow (manifestasi) menuju arah timur yang bertopografi tinggi hingga kearah barat

\section{DAFTAR PUSTAKA}

[1] B. J. Minsley, Modeling and Inversion of Self-Potential Data. B. S. Applied, 1997. 